\title{
Enrichment method for the isolation of bioactive actinomycetes from mangrove sediments of Andaman Islands, India
}

\author{
Baskaran, R. ${ }^{{ }^{\star}}$, Vijayakumar, R. $^{2}$ and Mohan, P. M. ${ }^{1}$ \\ ${ }^{1}$ Department of Ocean Studies and Marine Biology, Pondicherry University, Brookshabad Campus, Port Blair - 744103, \\ Andaman and Nicobar Island, India. \\ ${ }^{2}$ Department of Microbiology, Bharathidasan University College (W), Orathanadu - 614 625, India. \\ E-mail:sivan.thamilan@gmail.com \\ Received 11 March 2010; received in revised form 27 May 2010; accepted 4 June 2010
}

\begin{abstract}
Various pre-treatment methods and three different media were employed for the isolation of bioactive actinomycetes from mangrove sediments of Andaman and Nicobar Islands, India. Sediments from four different sites of mangrove forest were collected and pre-treated by dry heat method, and the media were supplemented with cycloheximide 80 $\mu \mathrm{g} / \mathrm{mL}$ and nalidixic acid $75 \mu \mathrm{g} / \mathrm{mL}$. The mean actinomycetes population density in sediment samples were recorded as $22 \mathrm{CFU}-10^{-6} / \mathrm{gm}$ in KUA medium followed by $12 \mathrm{CFU}-10^{-6} / \mathrm{gm}$ in AIA medium and $8 \mathrm{CFU}-10^{-6} / \mathrm{gm}$ in SCA medium. A total of 42 actinomycetes were isolated, and all the isolates were evaluated for their antibacterial activity against pathogenic bacteria on two different media. Among 42 isolates tested, 22 species were found to be antibacterial metabolite producer against test bacteria namely, Staphylococcus aureus, Bacillus subtilis, Salmonella typhi and Klebsiella pneumoniae. Particularly, the actinomycete strains such as A101, A102, A107, A116, A121, A125, A130, F101, F102, F104, F106, De101 and De102 significantly inhibited the growth of all bacteria which were tested. Of these strains, A107 was identified as Streptomyces spp. This strain had the maximum activity against all used pathogens on both medium. Hence, the isolation, characterization and studies of secondary metabolites of actinomycetes from mangrove sediments in Andaman and Nicobar Island could be a pathway for discovery of antibiotics from marine actinomycetes.
\end{abstract}

Keywords: Andaman Islands, Actinomycetes, pretreatment, characterization

\section{INTRODUCTION}

Marine environments are largely untapped source for the isolation of new microorganisms with potentiality to produce active secondary metabolites. Among such microorganisms, actinomycetes are of special interest, since they are known to produce chemically diverse compounds with a wide range of biological activities (Bredholt et al., 2008). The demand for new antibiotics continues to grow due to the rapid emerging of multiple antibiotic resistant pathogens causing life threatening infection. Although, considerable progress is being made within the fields of chemical synthesis and engineered biosynthesis of antibacterial compounds, nature still remains the richest and the most versatile source for new antibiotics (Kpehn and Carter, 2005; Baltz, 2006; Pelaez, 2006). Traditionally, actinomycetes have been isolated from terrestrial sources although, the first report of mycelium forming actinomycetes being recovered from marine sediments appeared several decades ago (Weyland, 1969). Recently, the marine derived actinomycetes have become recognized as a source of novel antibiotic and anticancer agent with unusual structure and properties (Jensen et al., 2005). Actinomycetes represent a ubiquitous group of microbes widely distributed in natural ecosystems around the world and especially significant for their role on the recycling of organic matter (Srinivasan et al., 1991).

The literatures suggested that, marine sediment sources are voluble for the isolation of novel actinomycetes with the potential to yield useful new products (Goodfellow and Haynes, 1984). However, it has been resolved whether actinomycetes form part of the autochthonous marine microbial community of sediment samples originated from terrestrial habitats and were simply carried out to sea in the form of resistant spores (Weyland, 1981; Goodfellow and Williams, 1983; Weyland and Helmke, 1988; Takizawa et al., 1993; Ravel et al., 1998). Microorganisms found in marine environments have attracted a great deal of attention, due to the production of various natural compounds and their specialized mechanisms for adaptation to extreme environment (Solingen et al., 2001). The pre-treatment including enrichment, physical and selective media may be used to study the ecology of actinomycetes in natural habitats such as soil or water samples (Jensen et al., 2005). Since marine sediments represent an environment which is markedly different from that associated with soil samples, it is not clear how effective the pre-treatment of such sediments would be for the recovery of bioactive actinomycetes. Marine sediment is an inexhaustible resource that has not been properly exploited. Few 
reports from the East Coast of India, suggests that soil is a major source of Actinomycetes (Sivakumar et al., 2005; Vijayakumar et al., 2007; Dhanasekaran et al., 2008; Vijayakumar et al., 2008). Correspondingly, the Andaman and Nicobar Island marine ecosystem is largely unexplored, and may provide a rich source of the microorganisms producing novel and efficient antimicrobial compounds. Hence, the present study was undertaken to isolate the bioactive actinomycetes from marine sediments of Andaman and Nicobar Islands by various pre-treatment methods using different media and evaluate the antibacterial potentiality of the isolates.

\section{MATERIALS AND METHODS}

\section{Study area}

Floating in splendid isolation coast of the Indian mainland is the archipelago of 572 emerald islands, islets and rocks known as Andaman and Nicobar Islands. This Union Territory is stretched over an area of more than $700 \mathrm{~km}$ from north to south with 36 inhabited islands. Once a hill range extending from Burma (Myanmar) to Indonesia, these undulating islands are covered with dense forests.

\section{Collection of mangrove sediment}

A total of four different mangrove sediment samples were collected from Bay of Bengal Coast (Lat. 11 '38' $46 \mathrm{~N}$; Long. 92 $40^{\prime} 71$ E) and Andaman Sea Coast (Lat.11 ${ }^{\circ} 35^{\prime} 47$. Long. $92^{\circ} 45^{\prime} 79$ ) of South Andaman Island, India. Samples were collected in sterile plastic containers in field and were transferred immediately to the laboratory and stored for further study.

\section{Isolation of actinomycetes from sediments}

The air dried sediment samples were ground aseptically with Pestle and Mortar, mixed thoroughly and passed through $2 \mathrm{~mm}$ sieve filter to remove gravel and debris. The samples were kept at $55^{\circ} \mathrm{C}$ for $5 \mathrm{~min}, 55^{\circ} \mathrm{C}$ for 60 $\min , 70^{\circ} \mathrm{C}$ for $15 \mathrm{~min}$ and $100{ }^{\circ} \mathrm{C}$ for $1 \mathrm{~h}$ in separate glass container for pre-treatment (Hayakawa and Nonomura, 1987; Hayakawa et al., 1991; Seong et al., 2001). Then, 10 fold serial dilutions of the sediment samples were made using sterile $50 \%$ sea water (Kim et al., 1994). About $0.1 \mathrm{~mL}$ of the serially diluted samples was spread over the Kuster's agar medium (Balagurunathan and Subramanian, 1992) g/L: glycerol 10 , casein $0.3, \mathrm{KNO}_{3} 3$, $\mathrm{K}_{2} \mathrm{HPO}_{4} 2, \mathrm{NaCl} 2, \mathrm{MgSO}_{4} \mathrm{0.05}, \mathrm{CaCo}_{3} \cdot 0.02, \mathrm{FeSO}_{4} 0.01$, agar 16; $\mathrm{pH} 7 \pm 0.1$ and $50 \%$ sea water, (Difco Chemicals). Starch casein agar medium (Wellington and Cross, 1983) $\mathrm{g} / \mathrm{L}$ : starch 10 , casein powder 1 , agar 15 ; sea water $50 \%$ and $\mathrm{pH} 7.2 \pm 0.2$ and Actinomycetes isolation agar medium g/L: sodium caseinate $2, \mathrm{~L}$ - asparagine 0.10 , sodium propionate 4, di-potassium phosphate 0.5 , magnesium sulphate 0.1 , ferrous sulphate 0.001 , agar 15 ; sea water $50 \%$ and $\mathrm{pH} 8.1 \pm 0.2$. All the three agar media were supplemented with $80 \mu \mathrm{g} / \mathrm{mL}$ of cycloheximide and $75 \mu \mathrm{g} / \mathrm{mL}$ of nalidixic acid (Himedia, Mumbai) to minimize the other bacterial and fungal growth. The plates were incubated at $28 \pm 2{ }^{\circ} \mathrm{C}$ for 28 days. After 5 days, the actinomycetes colonies grown on Petri plates were counted at regular intervals. All the morphologically different actinomycete colonies were sub-cultured on yeast extract malt extract agar medium (ISP No. 2) g/L: yeast extract 4 , malt extract 10 , dextrose $4,50 \%$ sea water, agar 20, pH 7.3 (Shirling, 1966) by streak plate technique. After growth appeared, the actinomycetes colonies were maintained in ISP No. 2 agar slants for further investigation.

\section{Screening for antibacterial activity}

All the isolated actinomycetes were tested for their antibacterial activity against several bacteria namely $B$. subtilis, S. typhi, S. aureus and $K$. pneumoniae. The antibacterial activity was carried by cross streak plate method (Lemos et al., 1985), single streak of the actinomycetes were made on Kuster's agar and modified nutrient agar medium [g/L: glucose 5 , peptone 5 , beef extract $3, \mathrm{NaCl} 5$, agar 15 and $\mathrm{pH} 7 \pm 0.1$ ] and incubated at $28 \pm 2{ }^{\circ} \mathrm{C}$ for 3 to 4 days (Kim et al., 1994). After observing a good ribbon like growth of the actinomycetes, the bacterial pathogens were streaked at right angle to the original streak of actinomycetes and incubated at $28 \pm$ $2{ }^{\circ} \mathrm{C}$. The inhibition zone $(\mathrm{mm})$ was measured after 24 and $48 \mathrm{~h}$. Control plates were also maintained without inoculating actinomycetes/bacteria to assess the normal growth of the pathogenic bacteria and actinomycetes.

\section{Secondary screening of A107: Preparation of antibiotic fermentation broth}

The strain A107 was cultured on agar slant at $28^{\circ} \mathrm{C}$ for 2 weeks, the mature spores were inoculated in fermentation broth containing $100 \mathrm{~mL}$ (Dextrose $2 \mathrm{~g}$, soya bean meal 2 $\mathrm{g}$, soluble starch $0.5 \mathrm{~g}$, peptone $0.5 \mathrm{~g}$, corn steep liquor $0.25 \mathrm{~g},\left(\mathrm{NH}_{4}\right)_{2} \mathrm{SO}_{4} 0.25 \mathrm{~g}, \mathrm{MgSO}_{4} \cdot 7 \mathrm{H}_{2} \mathrm{O} 0.25 \mathrm{~g}, \mathrm{~K}_{2} \mathrm{HPO}_{4}$ $0.002 \mathrm{~g}, \mathrm{NaCl} 0.4 \mathrm{~g}, \mathrm{CaCO}_{3} 0.2 \mathrm{~g}$, Sea water $50 \%$ ) and incubated at $30{ }^{\circ} \mathrm{C}$ on rotary shaker at $200 \mathrm{rpm}$ for $216 \mathrm{~h}$. The fermented broth was centrifuged at $10,000 \mathrm{rpm}$ at $4{ }^{\circ} \mathrm{C}$ for $20 \mathrm{~min}$ The supernatant was filtered using 0.45 $\mu \mathrm{m}$ spore size membrane filter (Millipore) the filter was collected as the antibiotic sample (Ruan, 1977). To determine the antibacterial spectrum, pathogenic bacteria were cultured on nutrient broth at $37^{\circ} \mathrm{C}$ for $24 \mathrm{~h}$; the cultures were swapped on Muller Hindan agar media. Three wells (6 $\mathrm{mm}$ in diameter) were prepared in each seeded agar plates and each well was filled with $100 \mu \mathrm{L}$ of the antibiotic fermentation broth strain A107. The plates were incubated at $37^{\circ} \mathrm{C}$ for 24 to $48 \mathrm{~h}$. The diameter of the inhibition zones was measured.

\section{Characteristics of high antibacterial active actinomycetes (A107)}

The slide culture of the high active streptomycetes was prepared on Kuster's agar medium and incubated at $28^{\circ} \mathrm{C}$ by using cavity slides. Periodical observation regarding 
spore morphology, arrangements and mycelium structure were recorded by using Nikon Microscope in $100 \mathrm{x}$ zoom. Cultural characteristics of A107 (growth, colouration of aerial and substrate mycelia, formation of soluble pigment) were tested in six different media including, yeast extract malt extract agar (ISP-2), oat meal agar (ISP-3), Inorganic salt starch agar (ISP-4), glycerol asparagine agar (ISP-5), tyrosin agar (ISP-7) and Kuster's agar medium (KU) according to the procedure of ISP. Biochemical test including $\mathrm{IM}-\mathrm{ViC}, \mathrm{H}_{2} \mathrm{~S}$ production, nitrate reduction, urease, catalase, starch gelatine and casein hydrolysis, haemolysis and TSI were also performed as recommended by ISP. Chemotaxanomical properties such as, analysis of cell wall sugar (Lechevalier et al., 1970) and cell wall amino acid analysis (Becker et al., 1965) were analysed. Utilization of carbon sources such as starch, dextrose, fructose, maltose, and mannitol and nitrogen sources namely D-alanine, L-arginine, and Ltyrosine were tested in Kuster's agar medium.

\section{RESULTS AND DISCUSSION}

Four different pre-heat treatments were employed for maximum isolation of actinomycetes. Of which, the soil treated at $70^{\circ} \mathrm{C}$ for 15 min yielded maximum of $22 \mathrm{CFU}$ of actinomycetes per gram of sediment at the dilution of $10^{-6}$ [Figure 2 (a)], whereas other treatments like at $100^{\circ} \mathrm{C}$ for 60 min yielded only $4 \mathrm{CFU} / 10^{-6}$, at $55^{\circ} \mathrm{C}$ for $5 \mathrm{~min}$ gave $12 \mathrm{CFU} / 10^{-6}$ and at $55^{\circ} \mathrm{C}$ for $60 \mathrm{~min}$ gave $15 \mathrm{CFU} / 10^{-6}$. Consequently, first two treatments did not allow any bacterial and fungal colonies to grow, whereas later treatments allowed the growth of bacterial and fungal colonies as 8 and $6 \mathrm{CFU} / 10^{-6}$ and 6 and $7 \mathrm{CFU} / 10^{-6}$ were recorded in the sediments treated at $55^{\circ} \mathrm{C}$ for 5 min and $55{ }^{\circ} \mathrm{C}$ for $60 \mathrm{~min}$ respectively (Figure 1 ). Hence it has been reported that, when the mangrove sediments were cultured without pre-treatment, the number of unwanted bacterial and fungal colonies were grown, [Figure 2 (b)] whereas the soil was air dried, they were decreased on culture plates. Also, the present study reported the dominance of other bacterial and fungal contamination inhibited the colonization of actinomycetes. Previously, this type of pre-treatment methods for isolation of actinomycetes has also been suggested by several researchers (Hayakawa and Nonomura, 1987; Hayakawa et al., 1991; Jensen et al., 1991; Kim et al., 1994; Seong et al., 2001).

Further, antimicrobial agents namely cycloheximide $(80 \mu \mathrm{g} / \mathrm{mL})$ and nalidixic acid $(75 \mu \mathrm{g} / \mathrm{mL})$ were supplemented in three different culture media namely Kuster's agar, starch casein agar and actinomycetes isolation agar. In our study, as much as 42 morphologically different actinomycetes isolates were isolated from the mangrove sediments. When compared with starch casein agar, Kuster's agar was found to be well supporting the isolation of more marine actinomycetes population. Maximum actinomycetes colonies (22 CFU $/ 10^{-6}$ ) were found on Kuster's agar followed by actinomycetes isolation agar $\left(12 \mathrm{CFU} / 10^{-6}\right)$ and starch casein agar $\left(8 \mathrm{CFU} / 10^{-6}\right)$. Thus, the present

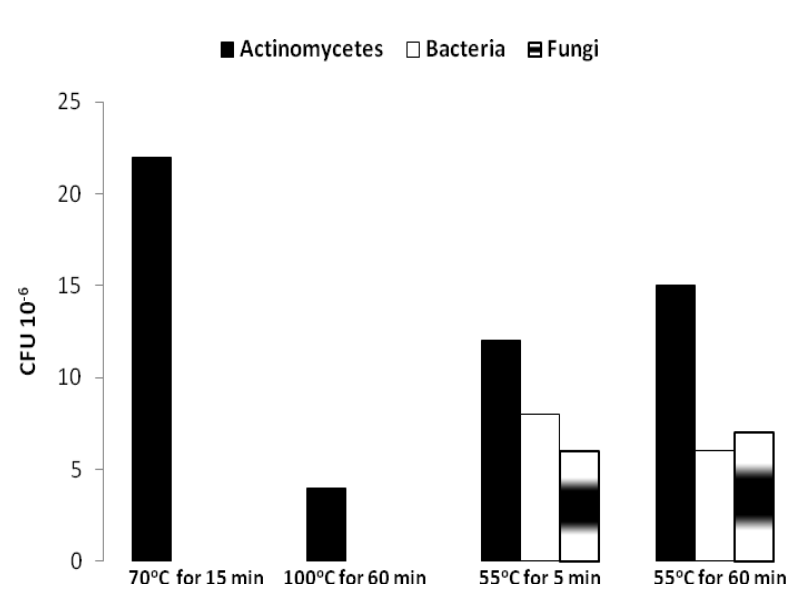

Pre-heat treatment

Figure 1: Various pre-heat treatments for isolation of actinomycetes from mangrove sediments

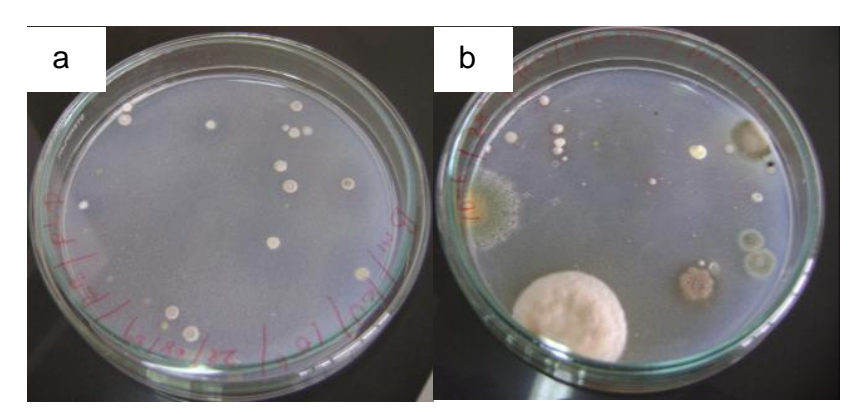

Figure 2: Isolation of actinomycetes from mangrove sediments (a) Pretreatment at $70{ }^{\circ} \mathrm{C}$ for $15 \mathrm{~min}$ and (b) without pretreatment

study reports that, the temperature at $70{ }^{\circ} \mathrm{C}$ for $15 \mathrm{~min}$ was suitable treatment method to isolate more actinomycetes colonies from the marine sediments, on Kuster's agar medium with the supplementation of cycloheximide $(80 \mu \mathrm{g} / \mathrm{mL})$ and nalidixic acid $(75 \mu \mathrm{g} / \mathrm{mL})$.

\section{Phenotypic characteristics of selected antagonistic actinomycetes (A107)}

Morphological characterization of A107, a broad spectral antagonistic isolates developed dark grey to white coloured spore mass. However, the strain A107 developed coffee brown coloured substrate mycelium. Further the strain A107 developed spiral nature spore chain in its aerial mycelium (Table 1). The details of morphological and biochemical characteristics, utilization of carbon and nitrogen sources, and chemotaxanomicals property of the test isolates are given in Table 1 . Sivakumar et al., (2005) reported that the characters can be used as marker by which an individual strain can be 
Table 1: Morphological and biochemical characteristics of high activity Actinomycetes (A 107)

\begin{tabular}{|c|c|}
\hline Properties & Streptomyces spp. \\
\hline \multicolumn{2}{|l|}{ Morphological characteristics } \\
\hline Spore morphology & Spiral \\
\hline Colour of aerial mycelium & Dark grey \\
\hline Colour of substrate mycelium & Coffee brown \\
\hline Spore mass & Dark grey \\
\hline \multicolumn{2}{|l|}{ Biochemical Characteristics } \\
\hline Indole production & - \\
\hline Methyl red & - \\
\hline Voges proskauer & - \\
\hline Citrate utilization & + \\
\hline $\mathrm{H}_{2} \mathrm{~S}$ production & - \\
\hline Nitrate reduction & - \\
\hline Urease & + \\
\hline Catalase & + \\
\hline Oxidase & - \\
\hline Melanin production & - \\
\hline Starch hydrolysis & + \\
\hline Gelatin hydrolysis & + \\
\hline Lipid hydrolysis & + \\
\hline Casien hydrolysis & + \\
\hline Haemolysis & + \\
\hline Triple Sugar iron & alk./alk. \\
\hline \multicolumn{2}{|l|}{ Chemotaxanomic characters } \\
\hline Whole cell sugar analysis & - \\
\hline Cell wall amino acid analysis & L-DAP \\
\hline \multicolumn{2}{|l|}{ Carbon source utilization } \\
\hline Starch & ++++ \\
\hline Dextrose & ++ \\
\hline Fructose & + \\
\hline Maltose & +++ \\
\hline Mannitol & ++++ \\
\hline \multicolumn{2}{|l|}{ Nitrogen utilization } \\
\hline D-alanine & +++ \\
\hline L-arginine & ++ \\
\hline L-phenylalanine & ++++ \\
\hline L-tyrosine & ++++ \\
\hline
\end{tabular}

recognized. Particularly, chemotaxonomy plays an important role in identification of actinomycetes to generic level. In this study, the test isolates contain mesodiaminopimelic acid and there were no sugar found in their cell wall. The isolate could utilize all the carbon sources and nitrogen sources (Table 1). The present investigation concluded that the physiological characteristics of actinomycetes varied depending on the available nutrients in the medium and the physical conditions. Upon the growth of the isolates on various media, Kuster's agar was observed to be the best medium for maximal growth. Further, the colour of diffusible pigment and the aerial and substrate mycelium produced by $\mathrm{A} 107$ isolates varied with different media. Pridham and Tresner (1974) reported that the colour of aerial mycelium
Table 2: Cultural characteristics of high active antagonistic actinomycetes on different media

\begin{tabular}{|c|c|c|}
\hline $\begin{array}{l}\text { Sl. } \\
\text { No }\end{array}$ & Name of the medium & $\begin{array}{l}\text { Streptomyces } \\
\text { spp. }\end{array}$ \\
\hline \multirow[t]{4}{*}{1.} & $\begin{array}{l}\text { Malt extract and yeast extract } \\
\text { aqar (ISP-2) }\end{array}$ & \\
\hline & Aerial mycelium & Dull white \\
\hline & Substrate mycelium & Dark yellow \\
\hline & Pigmentation & Nil \\
\hline \multirow[t]{4}{*}{2.} & Oat meal agar (ISP-3) & \\
\hline & Aerial mycelium & Grey \\
\hline & Substrate mycelium & Red \\
\hline & Pigmentation & Dark pink \\
\hline \multirow[t]{4}{*}{3.} & $\begin{array}{l}\text { Inorganic Salt Starch agar } \\
(\text { ISP-4) }\end{array}$ & \\
\hline & Aerial mycelium & Grey \\
\hline & strate mycelium & Yellowish green \\
\hline & Pigmentation & Nil \\
\hline \multirow[t]{4}{*}{4.} & Glycerol asparagines agar & \\
\hline & Aerial mycelium & Grey \\
\hline & Substrate mycelium & Light grey \\
\hline & Pigmentation & Nil \\
\hline \multirow[t]{4}{*}{5.} & Tyrosin agar (ISP-7) & \\
\hline & Aerial mycelium & Grey \\
\hline & Substrate mycelium & Yellow \\
\hline & Pigmentation & Nil \\
\hline \multirow[t]{4}{*}{6.} & Kuster's agar & \\
\hline & Aerial mycelium & Grey \\
\hline & Substrate mycelium & Dark yellow \\
\hline & Pigmentation & Pale pink \\
\hline
\end{tabular}

is considered to be an important character for the grouping and identification of actinomycetes. In the present study, A107, a high potential antibacterial compound producing actinomycete was cultured on six different culture media. The strain A107 produced pale pink coloured diffusible pigment on Kuster's agar medium (Table 2). Thus, the present investigation has been preclassified as high potential producers based on the colony morphology and phenotypic characteristics of actinomycetes (Table 1). Thus, it was concluded on the basis of the present and previous studies that the nutrient compositions of the medium greatly influenced the growth and morphology of organisms.

\section{Antibacterial activity of isolates}

The actinomycetes are noteworthy antibiotic producers, making the quarters of all known pharmaceutical products; the streptomycetes are especially prolific (Waksman, 1961; Lachevalier, 1989; Locci, 1989; Saadown and Gharaibeh, 2003). In the present study, out of 42 actinomycetes from the mangrove sediments of Andaman and Nicobar Islands, 22 (58.4\%) isolates had antibacterial activity against pathogenic bacteria. All the 42 isolates showed antibacterial activity with at least one test bacteria 
Table 3: Antibacterial activity of actinomycetes isolates

\begin{tabular}{|c|c|c|c|c|c|c|c|c|}
\hline \multirow[b]{3}{*}{$\begin{array}{l}\text { Isolate } \\
\text { code }\end{array}$} & \multicolumn{8}{|c|}{ Zone of inhibition (mm) } \\
\hline & \multicolumn{4}{|c|}{ Modified nutrient agar } & \multicolumn{4}{|c|}{ Kuster's agar } \\
\hline & 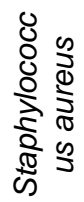 & 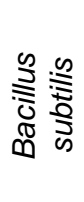 & 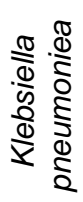 & $\underset{c}{\stackrel{2}{2}}$ & 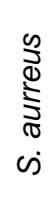 & 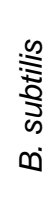 & 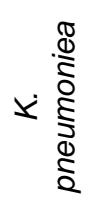 & ci \\
\hline A101 & 25 & 15 & 32 & 33 & 35 & 14 & 32 & 37 \\
\hline A102 & 12 & 12 & 12 & 12 & 30 & 16 & 30 & 34 \\
\hline A103 & 17 & - & 23 & 28 & 30 & 25 & 32 & 31 \\
\hline A104 & 20 & - & 23 & 27 & 37 & 19 & 32 & 35 \\
\hline A105 & - & - & 14 & 13 & 31 & - & - & 33 \\
\hline A107 & 30 & 30 & 30 & 32 & 33 & 33 & 35 & 30 \\
\hline A108 & 10 & - & - & - & 38 & 6 & - & 9 \\
\hline A110 & 34 & 19 & - & - & 36 & 16 & 35 & 35 \\
\hline A116 & 34 & 15 & 36 & 24 & 32 & 17 & 31 & 33 \\
\hline A120 & 9 & 5 & 5 & 5 & 47 & - & - & - \\
\hline A121 & 21 & 18 & 20 & 16 & 38 & 30 & 30 & 34 \\
\hline A125 & 25 & 12 & 18 & 19 & 37 & 18 & 38 & 37 \\
\hline A128 & - & - & 18 & - & 32 & 10 & - & 10 \\
\hline A130 & 24 & 11 & 30 & 30 & 32 & 10 & 35 & 33 \\
\hline F101 & 28 & 16 & 30 & 31 & 36 & 15 & 32 & 37 \\
\hline F102 & 20 & 20 & 20 & 20 & 35 & 16 & 36 & 36 \\
\hline F104 & 28 & 19 & 32 & 32 & 34 & 16 & 30 & 37 \\
\hline F105 & - & - & 15 & - & 44 & 8 & 12 & 10 \\
\hline F106 & 25 & 13 & 32 & 34 & 34 & 17 & 36 & 36 \\
\hline De101 & 22 & 18 & 30 & 32 & 35 & 15 & 18 & 37 \\
\hline De102 & 25 & 17 & 32 & 32 & 34 & 15 & 30 & 36 \\
\hline De103 & 15 & 5 & 13 & - & 36 & - & - & - \\
\hline
\end{tabular}

- : No activity

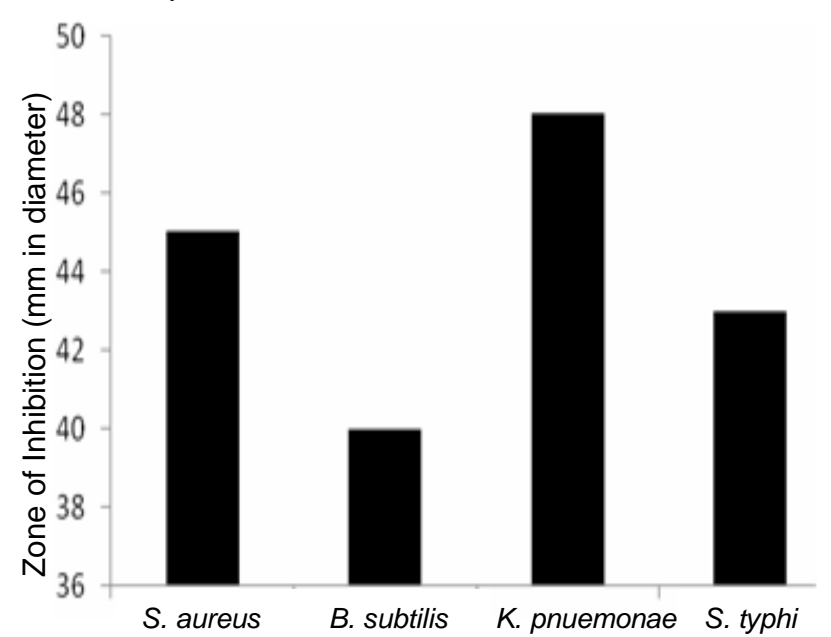

Figure 3: Secondary metabolic activity of Streptomyces spp. (A107)

on both modified nutrient agar and Kuster's agar media. Notably, the strains A101, A102, A107, A116, A121, A125, A130, F101, F102, F104, F106, De101 and De102 possessed supreme activity against all the bacterial pathogens tested on both modified nutrient agar and
Kuster's agar. The strains A105, A108, A128 and De103 showed more activity against tested bacteria on Kuster's agar than modified nutrient agar. Actinomycete strains such as A108, A128 and F105 inhibited one bacteria each [S. aureus $(10 \mathrm{~mm}), K$. pneumoniae $(18 \mathrm{~mm})$ and $K$. pneumoniae $(15 \mathrm{~mm})$ respectively] on modified nutrient agar, whereas on Kuster's agar the strains A108 and A128 produced maximum to moderate inhibitory zone against all the bacteria tested except $K$. pneumoniae, and the strain F105 inhibited the growth of all the four bacterial pathogens in the same media. In addition, all the actinomycete strains had remarkable antibacterial activity against $S$. aureus when grown on Kuster's agar medium.

On modified nutrient agar, the strain A107 produced maximum $(37 \mathrm{~mm})$ zone of inhibition against $S$. aureus, whereas on Kuster's agar, both strains A121 and A125 produced maximum zone of inhibition against $S$. aureus $(38 \mathrm{~mm})$ and $K$. pneumonia $(38 \mathrm{~mm})$ respectively. Interestingly, the other isolates also showed noticeable antibacterial activity against all the tested bacteria on both media. Comparatively, all the isolates produced maximum zone of inhibition when they were cultivated on Kuster's agar medium than modified nutrient agar (Table 3). A107 was found to be highly inhibiting pathogenic bacteria on both media; hence, the culture was selected for identification. Thus, it has been reported that, there are both quantitative and qualitative variations in the antibiotics produced by different genera and species. Substrates and habitats greatly influenced the production of antibiotics by actinomycete isolates.

Secondary metabolic activity of A107 showed highest antibacterial activity against $S$. aureus $(45 \mathrm{~mm})$ and $K$. pneumoniae $(48 \mathrm{~mm})$ given in Figure 3.

Correspondingly, Streptomyces spp. was isolated from the marine sponges Callyspongia diffusa, Mycale mytilorum, Tedania anhelans and Dysidea fragilis (Dharmaraj and Sumantha, 2009). From the initial screening, 94 cultures of Streptomyces were obtained and from these 58 cultures exhibited antagonism against bacteria, 36 strains against fungi and 27 strains exhibited broad spectrum activity against both. Similar type of work has also been reported by Remya and Vijayakumar (2008), from marine soils of Kerala, West Coast of India.

Though, the results of the present study gives clear picture about the significance of pre-treatment methods for the isolation of actinomycetes and revealed the marine actinomycetes from mangrove sediments of Andaman and Nicobar Islands to be a potent source of novel antibiotics. Studies on diversity of actinomycetes desires regular visits to the sampling stations, isolation from different substrates collected from the habitat and the usage of different culture media. Such attempts need to be continued both in the same area as well as from the adjoining places during various climatic conditions as to screen more isolates for novel therapeutics. 


\section{ACKNOWLEDGEMENT}

This work was accomplished with the help of University Grants Commission, Government of India, Research Fellowship in Sciences for meritorious students (RFSMS) to the first author.

\section{REFERENCES}

Balagurunathan, R. and Subramanian, A. (2001). Antagonistic Streptomyces from marine sediments. Advance Bioscience 20, 71-76.

Baltz, R. H. (2006). Marcel Faber Roundtable, Is our antibiotic pipeline unproductive because of starvation, constitution or lack of inspiration? Journal of Industrial Microbiology and Biotechnology 33, 507-513.

Becker, B. and Lechevalier, H. A. (1965). Chemical composition of cell wall preparation from strains are various from genera of aerobic Actinomycetes. Journal of Applied Microbiology 13, 236-243.

Bredholt, H., Fjaervik, E., Jhonsen, G. and Zotechev, S. B. (2008). Actinomycetes from sediments in the Trondhein Fjrod, Norway: Diversity and biological activity. Journal of Marine Drugs 6, 12-24.

Dhanasekaran, D., Panneerselvam, A. and Thajuddin N. (2008). An antifungal compound: 4' phenyl-1napthyl-phenyl acetamide from Streptomyces spp. DPTB16. Facta Universitatis Series: Medicine and Biology 15, 7-12.

Dharmaraj, S. and Sumantha, A. (2009). Bioactive potential of Streptomyces associated with marine sponges. World Journal of Microbial and Biotechnology 25, 1971-1979.

Goodfellow, M. and Haynes, J. A. (1984). Actinomycetes in marine sediments. In: Biological, Biochemical and Biomedical Aspects of Actinomycetes. Oritz-Oritz, L., Bojali, C. F. and Yakoleff, V. (eds.). Academic Press. New York, London. pp. 453-463.

Goodfellow, M. and Williams, E. (1983). Ecology of Actinomycetes. Annual Review of Microbiology 37, 189-216.

Hayakawa, M. and Nonomura H. (1987). Efficacy of artificial humic acid is a selective nutrient in HV agar used for the isolation of Actinomycetes. Journal of Fermentation Technology 65, 609-616.

Hayakawa, M., Sadaka, T., Kayiura, T. and Nonomura, H. (1991). New methods for the highly selective isolation Micromonospora and Microbispora. Journal of Fermentation and Bioengineering 72, 320-326.

Jensen, P. R., Dwight, R. and Finical, W. (1991). Distribution of Actinomycetes in near shore tropical marine sediments. Journal of Applied Environmental Microbiology 57, 1102-1108.

Jensen, P. R., Gontang, E., Mafnas, C., Mincer, T. J. and Fenical, W. (2005). Culturable marine Actinomycetes diversity from tropical Pacific Ocean sediments. Applied and Environmental Microbiology 7, 1039-1048.
Kim, C. M., Lec, K. H., Kwon, O. S., Shimazu, A. and Yoo I. D. (1994). Selective isolation of Actinomycetes by physical pre-treatment of soil sample. Journal of Applied Environmental Microbial Biotechnology 22, 222-225.

Kpehn, F. E., and Carter, G. T., (2005). The evolving role of natural products in drug discovery. Nature Reviews Drug Discovery 4, 206-220.

Lechevalier, M. P., and Lechevalier, H. A. (1970). chemical composition as a criterion in the classification of aerobic actinomycetes. International Journal of Systematic Bacteriology 20, 435-443.

Lechevalier, H. A. (1989). The actinomycetes III - A practical guide to generic identification of actinomycetes. Bergey's Manual of Systematic Bacteriology. Williams \& Wilkins Company. Baltimore. pp. 2344-2342.

Lemos, M. L., Toranzo A. E. and Barja J. L. (1985). Antibiotic activity of epiphytic bacteria isolated from intertidal seaweeds. Journal of Microbial Ecology 11, 149-163.

Locci, R. (1989). Streptomyces and related genera. In: Bergey's Manual of Systematic Bacteriology. Williams \& Wilkins Company, Baltimore. pp. 2541-2508.

Pelaez, F. (2006). The historical derive of antibiotic from microbial natural product - can history repeat? Journal of Biochemical Pharmacology 71, 981-990.

Pridham, T. G. and Tresner, H. D. (1974). Streptomycetaceae. In: Bergey's Manual of Determinative Bacteriology ( $8^{\text {th }}$ edn). Williams \& Wilkins Company, Baltimore, USA. pp. 747.

Ravel, J., Amoroso, M. J., Colwell R. R. and Hill R. T. (1998). Mercury resistant Actinomycetes from the Chesapeake Bay. FEMS Microbiology Letters 162, 172-184.

Remya, M. and Vijayakumar, R. (2008). Isolation and characterization of marine antagonistic Actinomycetes from West Coast of India. Facta Universitatis Series: Medicine and Biology 15, 13-19.

Ruan, J. S. (1977). The basis of taxonomy of actinomycetes. The Chinese Academic Press, Beijing. pp. 139-146.

Saadown, I. and Gharaibeh, R. (2003). The Streptomycetes flora of Badia region of Jordon and its potential as a source of antibiotic resistant bacteria. Journal of Arid Environment 53, 365-371.

Seong, C. H., Choi, J. H. and Baik, K. S. (2001). An improved selective isolation of rare actinomycetes from forest soil. Journal of Microbiology 17, 23-39.

Shirling, E. B. and Gottlieb, D. (1966). Methods for characterization of Streptomyces species. International Journal of Systematic Bacteriology 16, 312-340.

Sivakumar, K., Sahu, M. and Kathiresan, K. (2005). Isolation and characterization of streptomycetes producing antibiotic from mangrove environment. Asian Journal of Microbial Biotechnology and Environmental Science 7, 457-764. 
Solingen, P., Dean, V. M., Wilhelmus, A. H. K. Christopher, B., Robertus, B., Scott, D. P. and Brian E. J. (2001). from a novel Streptomycetes isolated from an East African Soda Lake. Extremophiles 5, 333-341.

Srinivasan, M. C., Laxman R. S. and Deshpande M. V. (1991). Physiology and nutrition aspects of actinomycetes - An overview. World Journal of Microbial and Biotechnology 7, 171-184.

Takizawa, M., Colwell R. and Hill R. T. (1993). Isolation and diversity of Actinomycetes in the Chesapeake Bay. Applied Environmental Microbiology 59, 9971002.

Vijayakumar, R., Muthukumar, C., Thajuddin, N., Pannerselvam A. and Saravanamuthu R. (2007). Studies on the diversity of Actinomycetes in the Palk Strait region of Bay of Bengal, India. Actinomycetologica 21, 59-65.

Vijayakumar, R., Seethalakshmi, V., Anitha, S. and Saravanamuthu, R. (2009). Isolation and characterization of antagonistic actinomycetes from Coimbatore soils, Tamil Nadu, India. Journal of Science Trance Environmental Technology 2, 191201.

Waksman, S. A. (1961). The Actinomycetes classification identification and description of genera and species. Williams \& Wilkins Company, Baltimore. pp. 261-292.

Wellington, E. M. H. and Cross, T. (1983). Taxonomy of antibiotic producing Actinomycetes and new approaches to their selective isolation. In: "Progress in industrial microbiology?" Bushell, M. E. (eds.). Elsevier, Amsterdam. pp. 36.

Weyland, H. (1969). Actinomycetes in North Sea and Atlantic Ocean sediments. Nature 223, 858.

Weyland, H. (1981). Characteristics of actinomycetes isolated from marine sediments. Zentralblatt für Bakteriologie, Parasitenkunde, Infektionskrankheiten und Hygiene Abt I suppl II, 309 - 314.

Weyland, H. and Helmke, E. (1988). Actinomycetes in the marine environment. In: The Biology of Actinomycetes. Okami, Y., Beppu, T. and Nagamura H. (eds.). Japan Scientific Society Press, Tokyo. pp. 294. 